\title{
Utilization of Village Funds in Community Empowerment Efforts (Study in Tewah Pupuh Village, Benua Lima District, East Barito Regency)
}

\author{
Rini Agustina ${ }^{1 *}$, Hary Supriadi ${ }^{2}$, Andi Tenri Sompa ${ }^{3}$ \\ ${ }^{1,2}$ Master Program of Science in Development Administration, Lambung Mangkurat University, Indonesia \\ ${ }^{3}$ Department of Government Science, Faculty of Social and Political Science, Lambung Mangkurat University, Banjarmasin, Indonesia
}

\author{
DOI: $10.36348 /$ SJEF.2019.v03i10.001
}

| Received: 26.09.2019| Accepted: 03.10.2019| Published: 14.10.2019

*Corresponding author: Rini Agustina

\section{Abstract}

The Village Fund is one of the government policies that began in 2015, which seeks to place villagers as actors in village development and community empowerment in order to improve community welfare. The use of Village Funds is prioritized $80 \%$ for development and $20 \%$ for community empowerment. This research is a descriptive qualitative research oriented to describe the relationship between variables that influence the emergence of phenomena. The analysis tool used in this study is CIPP (Context, Input, Process, Product). The results showed that the utilization of the Village Fund for Community Empowerment was not on target. Village Funds contribution is dominated by apparatus or honorarium expenditure. In terms of context, data collection activities are not yet optimal in terms of community needs. From the input aspect shows that the identification of the strategy is not optimal so that the goal is not achieved. From the aspect of the process, the low participation in the management of the Village Fund and from the aspect of the product, has not yet reached the goal of utilizing the Village Fund. Based on these results, the government of East Barito Regency through the Regional Apparatus Organization related to the Village Fund policy can carry out training on Village Fund management for the village head and village apparatus and related institutions in the village so that the utilization of the Village Fund can improve the welfare of the village community.

Keywords: community empowerment, village development, village funds.

Copyright @ 2019: This is an open-access article distributed under the terms of the Creative Commons Attribution license which permits unrestricted use, distribution, and reproduction in any medium for non-commercial use (NonCommercial, or CC-BY-NC) provided the original author and source are credited.

\section{INTRODUCTION \\ Research Background}

Based on Law No. 23 of 2014 concerning Regional Government, the implementation of regional government is directed to accelerate the realization of community welfare through improved services, community empowerment and enhancing regional competitiveness by taking into account the principles of democracy, equity, justice and the uniqueness of a region in the system of the Unitary State of the Republic of Indonesia (Homeland). Referring to the administrative authority that is smaller than the local government is the village. The village is a representation of the smallest legal community that grows and develops as an inseparable part of the life structure of the Indonesian people as the spearhead of development and improvement of people's welfare.

Recognition of the existence of villages is accommodated in Law Number 23 of 2014 concerning Regional Government and Law Number 6 of 2014 concerning Villages. Village rights and obligations are clearly and clearly regulated in the Law. The village has the right to regulate and manage the interests of the community based on the rights of origin, customs, social and cultural values of the village community, determine and manage village institutions and get a source of income.

The village is obliged to protect and maintain the unity and harmony of the village community within the framework of national harmony and the integrity of the Republic of Indonesia. This is related to improving the quality of life of rural communities, developing democratic life, developing empowerment of rural communities and providing improved services to the community. In realizing the establishment of a village government that is supported by adequate sources of funds. The presence of village autonomy, the village is expected to be able to organize governance independently, from by and for the people, has the initiative and prioritizes the participation of local 
village communities [10]. But generally the obstacles faced by the village government to realize the development and empowerment of rural communities are related to budget constraints.

Village Funds are funds sourced from the State Revenue and Expenditure Budget (APBN) which are intended for villages and traditional villages that are transferred through the Regency / city Regional Revenue and Expenditure Budget (APBD) and are used to finance government administration, development, community empowerment and society. The Village Fund aims to improve the welfare and equity of village development through improving public services in the village, advancing the village economy, overcoming development disparities between villages and strengthening rural communities as subjects of development [1].

In Law Number 6 of 2014, it is explained that the Village Fund must be managed in an orderly, obedient to the provisions of the legislation, efficient, economical, effective, transparent and responsible with due regard for a sense of justice and compliance as well as prioritizing the interests of the community. In order to support the realization of good governance (governance), village management, especially related to the utilization of the Village Fund, is always carried out by prioritizing transparent, accountable and participatory principles.

The amount of the Village Fund allocated per village varies according to formula allocation. Formula allocation is an allocation calculated by taking into account the number of villagers, the area of the village and the level of village poverty and the level of geographical difficulty. Data on the number of villagers, the area of the village, the level of poverty and the level of geographical difficulties are sourced from the relevant ministries and / or institutions that conduct government affairs in the field of statistics. The level of geographical difficulty is determined by factors of basic service availability, infrastructure conditions, transportation and communication from village to district.

Based on Ministry of Finance data, since 2015 the central government has budgeted Village Funds large enough to be given to villages. In 2015, the Village Fund was budgeted at Rp. 20.7 trillion with an average of each village getting an allocation of Rp. 280 million. In 2016, the Village Fund budget increased to Rp. 46.98 trillion with an average of each village getting Rp. 628 million per village throughout Indonesia including 101 villages from East Barito District.

East Barito Regency is one of the autonomous regions in Central Kalimantan which was approved as an autonomous region based on Law Number 5 of 2002 concerning the Establishment of the Katingan Regency, Seruyan Regency, Sukamara Regency, Lamandau Regency, Gunung Mas Regency, Pulang Pisau Regency, Murung Regency Raya and East Barito District in the Province of Central Kalimantan. The total area of East Barito Regency is 3,834 KM2 or 2.5\% of the area of Central Kalimantan province which covers 10 (ten) districts, 3 (three) villages and 101 (one hundred and one villages).

The priority for the use of Village Funds as stipulated in the Regulation of the Minister of Villages, Disadvantaged Regions and Transmigration Number 5 of 2015 concerning the Determination of Priorities for the Use of Village Funds is to finance village development expenditure and empower village communities. Article 16, Government Regulation of the Republic of Indonesia Number 60 of 2014 concerning Village Funds sourced from the State Revenue and Expenditure Budget, the distribution of Village Funds is carried out in stages in the current fiscal year with the following provisions: phase I in April by 40\%, phase II in August by $40 \%$ and stage III in October by $20 \%$. Based on the Regulation of the East Barito Regent No. 9 of 2016 concerning the procedures for Distribution, Determination of Details and Use of Village Funds in East Barito Regency, the 2016 Budget Year prioritizes the use of Village Funds to finance $80 \%$ development and finance $20 \%$ community empowerment.

Regarding the presentation of the amount of the village fund, this article describes the priority of using the Village Fund for village development. Certainly referring to the allocation of village development that is improving the welfare of rural communities and the quality of human life and poverty alleviation through meeting basic needs, construction of village facilities and infrastructure, development of local potential and sustainable use of natural resources and the environment [9].

\section{METHODS}

Based on the main characteristics of the problem, this research is a descriptive study. Descriptive research is a research model that is oriented towards describing the relationship between variables or factors that influence the emergence of a social phenomenon that is used as an object of study [2]. Based on the analysis model, this descriptive study is a qualitative descriptive model. The study design was used as an evaluation study. Evaluative research is more oriented to efforts to explain aspects of the benefits or results of an activity to be input for further improvement activities. The type of data used in this study are primary data (including: interviews and observations) and secondary data (documents or physical data in the form of Village Income and Expenditure Accountability Reports). In detail, the following is the presentation of the research resource table: 
Rini Agustina et al., Saudi J Econ Fin, Oct 2019; 3(10): 445-452

\begin{tabular}{|c|c|c|}
\hline No & Interviewees & Information obtained \\
\hline 1. & Village Head & $\begin{array}{l}\text { 1. General Conditions of Village Communities } \\
\text { 2. Village Fund Management }\end{array}$ \\
\hline 2. & $\begin{array}{l}\text { Village Officials: } \\
\text { a. Village secretary } \\
\text { b. Head of Affairs and Head of Section }\end{array}$ & Making a Work Plan \\
\hline 3. & Chairman of the Village Consultative Board & $\begin{array}{l}\text { Supervision and Coordination Function between } \\
\text { institutions }\end{array}$ \\
\hline 4. & Family Welfare Programme (PKK) Management & Participation in Community Empowerment \\
\hline 5. & $\begin{array}{l}\text { Head of Neighbourhood/Community } \\
\text { Association }\end{array}$ & Community involvement in the use of Village Funds \\
\hline 6. & Youth Organization Management & Community involvement in the use of Village Funds \\
\hline 7. & $\begin{array}{l}\text { The community } \\
\text { a. Traditional figure } \\
\text { b. Religious leaders }\end{array}$ & Community needs \\
\hline 8. & $\begin{array}{l}\text { Toddler and integrated health service post } \\
\text { Administrators }\end{array}$ & Village Fund Utilization \\
\hline 9. & $\begin{array}{l}\text { Elderly and integrated health service post } \\
\text { Administrators }\end{array}$ & Village Fund Utilization \\
\hline 10. & Early childhood education management & Village Fund Utilization \\
\hline
\end{tabular}

The location of this research was conducted at Tewah Pupuh, Benua Lima District, and East Barito Regency from February to August 2018. The analytical tool in this study was CIPP (Context, Input, Process and Product). CIPP is an evaluation component that provides benefits and contributions in implementing a program. Basically, the evaluation model developed by Daniel Stuffleabem helps in decision making. The CIPP covers several aspects as follows: Context Aspect, Input Aspect, Process Aspect, and Product Aspect. Testing the validity or validity of the data in qualitative research methods uses different terms with a qualitative approach [3, 4]. One aspect of truth value in qualitative methods using reference material is supporting data to prove the data that has been found by researchers [5]. Based on this to get the validity of the data in the study used triangulation of techniques and sources.

\section{RESULTS AND DISCUSSIONS}

In general, evaluation is an evaluation of the implementation of a program that has been carried out and will be used to predict, calculate and control the implementation of the program in the future so that it is better. Thus the mission of the evaluation is the improvement or refinement in the future that will come from the implementation of a program.

According to Siagian [6] evaluation is the process of measuring and comparing the results of work that were actually achieved with the results that should have been achieved. Furthermore, Mulyadi also explained that evaluation is an effort to gather information about a program, activity or project [7]. The information referred to is very important in terms of decision making, among others, to improve the program, refine further activities, stop an activity and spread the ideas that underlie a program and activities. The information collected must meet scientific, practical, appropriate and appropriate requirements with the underlying values in every decision making.
Program evaluation activities are curiosity to see whether the program's goals have been achieved or not [8]. If it has been achieved then how is the quality of the achievement of these activities and if it has not been achieved then which part of the plan that has been made but not yet achieved and what causes the plan has not been achieved. Evaluation is an activity to gather information about a program that has been determined so that the information will be used to determine the right choice in making a decision. The form of evaluation in the form of recommendations for making decisions. The following is a description of the findings of the CIPP aspect, the dominant factors influencing the non-utilization of the Village Fund for Community Empowerment, and the form of participation.

\section{Findings from aspects of CIPP (Context, Input, Process, Product)}

\section{Context Aspect}

The context evaluation component in the research on the Utilization of Village Funds in Community Empowerment efforts in Tewah Pupuh Village, Benua Lima District is the background of the Village Fund policy, the objectives and objectives of the Village Fund policy program sourced from the State Budget (APBN). To find out the extent of the context aspects in the utilization of the Village Fund in the village of Tewah Pupuh then first analyze the objectives of the Village Fund policy with village demographics before and after the implementation of the Village Fund policy. The Village Fund is a central government policy set forth in Nawacita that is to develop Indonesia from the periphery by strengthening regions within the framework of the Republic of Indonesia. The implementation of the policy is the issuance of Law Number 23 of 2014 concerning Regional Government and Law Number 6 of 2014 concerning Villages. The design of the Village Fund policy is as follows: 
- The Village Fund is intended to finance governance, development, empowerment and society.

- The purpose of the Village Fund is to improve the welfare and equitable development of villages through improving public services in the village, advancing the village economy, addressing development disparities between villages and strengthening rural communities as subjects of village development.

- The Village Fund is prioritized for community empowerment and village development.

- Empowerment of rural communities is related to efforts to develop independence and welfare of the community by increasing knowledge, attitudes, skills, behavior, abilities, awareness and utilizing resources through the determination of policies, programs, activities and assistance in accordance with the essence of the problems and priority needs of rural communities.

- Village development is related to efforts to improve the welfare of rural communities and the quality of human life and poverty reduction through meeting basic needs, construction of village facilities and infrastructure, development of local potential and sustainable use of natural resources and the environment.

Village demographics that describe the natural conditions and changes that occur in the community have a very important role. The assessment of Village Fund utilization can be measured by looking at the extent to which program objectives can be achieved. based on the details of the 2016 Village Fund allotment in the village of Tewah Pupuh is for village development and community empowerment with a percentage of $80 \%$ for village development and $20 \%$ for community empowerment. In terms of context, this is in accordance with regulations that govern the priority of using village funds.

Improving welfare, equitable village development through improving public services in the village, advancing the village economy, overcoming development gaps between villages and strengthening communities as subjects of development are the main objectives of the Village Fund policy. Based on the results of the study, of the total number of 325 families, 201 families included in the category of underprivileged families.

In the context of aspects other than regulations related to the Village Fund, the vision and mission of the elected village head is also the basis in preparing the Village Fund designation plan. The vision of Tewah Pupuh village is the development of Tewah Pupuh Village which is Dignified, Advanced, Evenly, Prosperous and Fair. While its mission is to improve and improve village administration and village officials, organize and regulate village market management, infrastructure development in each neighbourhood such as farm roads and walkways, opening and printing rice fields, improving village roads Tewah Pupuh - Gumpa, proposing the connection of local water supply utility or clean water facilities, sports facilities and work skills training for young people.

\section{Input Aspects}

The input evaluation component in this study includes available resources and work programs. The input aspect relates to how the use of available resources and strategies must be considered to achieve a program. The input aspect has a very important role in the implementation of a program or policy. In utilizing the Village Fund, there are several factors that are part of the input aspect, namely the planning process, available funds and human resources, both village officials, the community and regulations related to the Village Fund.

Technically, Village Fund planning is prepared by the village secretary and head of planning and financial affairs. The Village Fund planning is based on the results of deliberations or joint meetings with all elements of the Tewah Pupuh village community. In the village of Tewah Pupuh prior to the Multi Stakeholder Consultation Forum for Development Planning (Musrenbangdes), village officials first held a meeting with the neighbourhood to collect data on community needs. The results of the meeting were used by village officials to be the basis for the Musrenbangdes activities, which were scheduled for the Benua Lima sub-district.

The development planning process in the village of Tewah Pupuh began with the preparation of the Village Medium Term Development Plan (RPMJDes), which is a manifestation of the vision and mission of the politically elected village head integrated with the development of the East Barito Regency. The RPMJDes is a legal product determined through a Village Regulation with a period of six years in accordance with the tenure of the village head.

Based on the results of interviews with the village head of Tewah Pupuh, in the process of drafting the village medium term development plan, the principles of community empowerment are always aimed at increasing community welfare and independence, active and direct community participation in the development process, taking sides with the community, being open in the sense of every development process. can be seen and known directly by the community, accountable or can be properly accounted for both the district government and the village community, efficient and effective in accordance with the potential of natural resources and human resources in the local village and sustainable. 
According to the explanation of the village head of Tewah Pupuh, in the process of drafting the village medium term development plan, the above principles have been applied even though they have not been maximized because it is not easy to implement them. The limited resources of the village apparatus is one of the factors inhibiting the maximum implementation. The Crushing Whole RPJMD is specifically spelled out in the Village Government Work Plan (RKPDes) compiled through musrenbangdes activities.

Fertilizer Musrenbangdes activities for 2016 Fiscal Year activities were carried out in 2015 attended by the village head, village apparatus, the Village Consultative Body, elements of the village institution, the head of Neighbourhood/Community Association, the sub-district and the team from the Office of Empowerment and Village Administration. At the village musrenbang activity, 50 people were invited and only 26 people attended or $50 \%$ attended. This shows the low participation of Tewah Pupuh community in village government activities.

The Village Fund itself is village income sourced from the National Budget. The availability of Village Funds which is influenced by the area, poverty level and geographical difficulty level is an annual cycle policy starting in 2015. Because the Village Fund is an annual cycle policy, the Village Fund management process takes place repeatedly every year. The potential of village government apparatus resources is very influential in the implementation of Village Fund management. The low level of education both the education of the village government apparatus and the education of the village community in general affect the implementation of the Village Fund. The level of education also affects community participation, especially in the implementation of village funds, among others in terms of decision making, understanding of community norms, ability to solve or provide solutions to problems and lack of insight.

In the input aspect, the human resource factor is a weakness or an obstacle in the utilization of the Village Fund at Tewah Pupuh. These weaknesses occur in the village government apparatus and in the village community of Tewah Pupuh. To overcome these problems, it is necessary to carry out training or technical guidance related to the utilization of the Village Fund at Tewah Pupuh. Another factor influencing the input aspect is the low understanding of regulations related to village development, especially those related to the use of Village Funds.

\section{Process Aspects}

The process evaluation component in this study includes the procedures for implementing the empowerment program and community participation in the utilization of the Village Fund. The implementation of Tewah Pupuh village development from the Village Fund has involved the community in mutual cooperation. Mutual cooperation is a form of direct community involvement or participation in village development where the community can see, work on and supervise village development activities. Utilization of Village Funds for community empowerment cannot yet be said to be effective. This is due to the lack of poverty. Supervision of the management of the utilization of the Village Fund is carried out by internal parties and external parties. Oversight from internal parties is carried out by the Village Consultative Body representing the community. External oversight is carried out by the District, Inspectorate, the Office of Empowerment and Village Administration and the Finance and Development Supervisory Agency (BPKP).

\section{Product Aspects}

The product evaluation component in this study is the competence of the Village Apparatus. The purpose of the product evaluation is to assess the results of the utilization of the Village Fund in Cewah Pupuh. Achieved or not achieved targets are assessment products. Evaluation of the utilization of the Village Fund is not only by measuring the suitability of the budget with the implementation in the field. How much has the Village Fund benefited from the product evaluation results. Not all people in the village of Tewah Pupuh can benefit from the Village Fund. This is due to the limited amount of budget.

From the explanation above, it can be compiled the evaluation framework of the CIPP model in the research on Village Fund Utilization in Community Empowerment efforts as follows: 


\begin{tabular}{|c|c|c|c|c|c|}
\hline No & Aspect & Component & Aim & $\begin{array}{c}\text { Indicator of } \\
\text { Success }\end{array}$ & Evaluation result \\
\hline 1. & Context & $\begin{array}{l}\text { Policy Background: } \\
\text { 1. Law No. } 23 \text { of } 2014 \text { concerning } \\
\text { Regional Government. } \\
\text { 2. Law No. } 6 \text { of } 2014 \text { concerning } \\
\text { Villages. } \\
\text { 3. Government Regulation No. } 60 \text { of } \\
\text { 2014 concerning Village Funds } \\
\text { Sourced from the State Budget. } \\
\text { 4. Permendes, Development of } \\
\text { Disadvantaged Regions and } \\
\text { Transmigration No. } 5 \text { of } 2015 \\
\text { concerning Priorities for the Use of } \\
\text { Village Funds }\end{array}$ & $\begin{array}{l}\text { Increasing prosperity } \\
\text { and equitable } \\
\text { development through } \\
\text { improving public } \\
\text { services in the village, } \\
\text { advancing the village } \\
\text { economy, overcoming } \\
\text { development gaps } \\
\text { between villages and } \\
\text { strengthening rural } \\
\text { communities as the } \\
\text { subject of } \\
\text { development. }\end{array}$ & $\begin{array}{l}\text { The relevance of } \\
\text { objectives and } \\
\text { regulations. }\end{array}$ & $\begin{array}{l}\text { Compilation of } \\
\text { activity documents. }\end{array}$ \\
\hline 2. & $\begin{array}{l}\text { Feedbac } \\
\mathrm{k}\end{array}$ & $\begin{array}{l}\text { Village Apparatus Resources, Activity } \\
\text { schedule }\end{array}$ & $\begin{array}{l}\text { Implementation } \\
\text { Procedures } \\
\text { activities }\end{array}$ & $\begin{array}{l}\text { The existence of } \\
\text { musrenbangdes } \\
\text { activities, and other } \\
\text { meetings and } \\
\text { socialization }\end{array}$ & \multirow{3}{*}{$\begin{array}{l}\text { - Implementation of } \\
\text { village deliberations } \\
\text { in accordance with } \\
\text { the schedule of } \\
\text { activities. } \\
\text { - Lack of community } \\
\text { participation in } \\
\text { activities } \\
\text { - There is no increase } \\
\text { or decrease in } \\
\text { poverty }\end{array}$} \\
\hline 3. & Process & $\begin{array}{lrr}\text { Implementation of } & \text { Community } \\
\text { Empowerment and } & \text { Community } \\
\text { Participation Programs } & \end{array}$ & $\begin{array}{l}\text { Implementation of } \\
\text { Community } \\
\text { Empowerment and } \\
\text { Community } \\
\text { Participation activities }\end{array}$ & Activity & \\
\hline 4. & Product & Activity Report & Meeting needs & $\begin{array}{l}\text { There is an increase } \\
\text { in prosperity and } \\
\text { reduction } \\
\text { poverty }\end{array}$ & \\
\hline
\end{tabular}

\section{Dominant Factors that Influence the Utilization of Village Funds for Community Empowerment}

\section{Low Potential Resources}

The potential of village government apparatus resources is one of the important factors that must be prepared in relation to realizing community welfare through the Village Fund. The low performance of village government officials such as complaints about the quality of services, ignorance and even dissatisfaction from the community about various programs is due to the low potential of village apparatus resources.

The potential of village apparatus resources itself is influenced by the level of formal education and training/technical guidance that has been followed by the Village Government apparatus, especially those related to Village Fund management. The potential of village apparatus resources influences the performance of the village government. Based on data on the education level of the Tewah Pupuh village apparatus, the average formal education level is a senior high school graduate. As for the training/technical guidance/outreach/consultation activities, the village government has budgeted a sizeable nominal of Rp20,000,000.

The suboptimal utilization of the Village Fund in community empowerment efforts shows that the role of the village apparatus in managing the Village Fund is not yet optimal. The lack of understanding of the village apparatus in managing the Village Fund caused the community not to feel the benefits of the Village Fund which led to an increase in the welfare of the community in the village of Tewah Pupuh. Utilization of Village Funds is considered not optimal shown by the absence of a reduction in the number of poverty even though the amount of funds disbursed continues to increase every year.

\section{Coordination between institutions is not yet running optimally}

Since the enactment of Law Number 6 of 2014 concerning villages, the village government has been given facilities through the Village Fund policy to run village governance as a concrete form of developing Indonesia from the periphery. The success in realizing the welfare of the village community is influenced by the coordination between the institutions implemented. In the village, the Village Consultative Body (BPD) is an institution that carries out the functions of digging, accommodating, gathering and channeling the aspirations of the village community. The aspirations and needs of the village community will not be properly channeled if the coordination with the village government is not properly established or not in accordance with the provisions. In the village of Tewah Pupuh, coordination between institutions is more familial. The nature of this family actually leads to things that are not in accordance with the laws and regulations. 


\section{Forms of Community Participation}

Community participation is an implementation of community empowerment. Participation is a factor that determines the success or failure of community empowerment. The community itself is the main actor in community empowerment. The greater the involvement of the community in village government activities, the greater the benefits that can be felt by the local community and vice versa. Community participation in the use of Village Funds is not only involved in decision making but the community is also involved in identifying problems and potentials owned by the community

Related to community participation in the use of Village Funds more so that the use and management of Village Funds can be targeted and the benefits can be felt by the community. What happened in Tewah Pupuh Village, Benua Lima Subdistrict, the use of Village Funds was not optimal involving the local community. This results in dissatisfaction and even the community's ignorance of the benefits of the Village Fund and does not even affect poverty rates. The factor of the lack of socialization of the Tewah Pupuh village government apparatus regarding the Village Fund Program so that many people do not know about the Village Fund. The manifestation of Tewah Pupuh village community participation is illustrated in the following activities:

- Participation in decision making

Participation at the decision making stage was manifested in the presence of the community in meetings as evidenced by the attendance list in which approximately 100 people invited were attended by only approximately 33 people at the Village Development Plan Deliberation meeting.

- Participation at the implementation stage The manifestation of this participation in the implementation phase was direct community involvement in various activities, especially those sourced from the Village Fund. Mutual cooperation is one form of this participation. Village communities are very easy with the invitation to work together, but from the implementation of mutual cooperation, the community does not really care about the program that they carried out in mutual cooperation.

- Participation in the stage of receiving benefits Village Fund beneficiaries are people or institutions that receive, manage Village Funds aimed at improving welfare. Referring to the prevailing laws and regulations that the beneficiaries of the Village Fund are all village communities through improving public services in the village, advancing the village economy, addressing development disparities between villages and strengthening village communities as subjects of development with the aim of improving the welfare of the village community. In general, the Tewah Pupuh community of Benua Lima
District has not felt the impact directly related to the use of the Village Fund.

- Participation in the evaluation phase

Participation in the evaluation phase can be feedback on activities that have already been carried out. Feedback can be either satisfied or dissatisfied with the benefits of the program that has been disbursed.

The forms of participation of Tewah Pupuh village community in the management of the Village Fund are as follows:

\section{Vertical participation}

A condition where the Tewah Pupuh community is involved in the management of the Village Fund where the community acts as a subordinate or invited guest to be present at the Tewah Pupuh village meeting.

\section{Horizontal participation}

The condition in which a group of Tewah Pupuh villagers participated together with another group.

In addition to participating in vertical and horizontal forms, the Tewah Pupuh community is also involved in managing Village Funds in physical and non-physical forms.Community involvement in the activities of building Paud buildings, building bridges, making wells and making fences is a form of community participation in physical form while community participation in village meetings or meetings is a form of non-physical participation.

\section{CONCLUSION}

The priority of using the Village Fund for community empowerment aims to reduce poverty and increase access to economic resources including improving the quality of the village planning process, supporting economic activities both developed by Village Enterprises (BUM Desa) and by village community business groups, forming and increasing the capacity of village community empowerment cadres, organizing through the formation and paralegal facilities to provide legal assistance to villagers, organizing health promotion and clean and healthy living movements, supporting village activities and community forest management in the village and community forests and increasing the capacity of community groups such as productive economic enterprises, women, farmers, poor people, fishermen, craftsmen, observers and protection of children, youth and other groups according to village conditions. However, the utilization of village funds in Tewah Pupuh Village, Benua Lima District, East Barito Regency was considered not on target.

Reviewing the utilization of village funds is based on an analysis of CIPP aspects that show results, 
such as: 1) Context Evaluation of Community Needs that are not accommodated in planning, 2) Evaluation of Inputs, looking at low levels of education, village government apparatus resources and low community participation resulting in ineffective planning, 3) Process Evaluation, seeing the low participation of Tewah Pupuh villagers in the management of Village Funds ranging from planning, implementation to evaluation, 4) Product Evaluation seen from the achievement of the objectives of the utilization of Village Funds has not been reached (Low resources and community participation in Tewah Pupuh village Benua Lima sub-district in general and the low resources of the village government apparatus specifically).

\section{REFERENCES}

1. Suharto, E. (2009). Membangun Masyarakat Memberdayakan Rakyat. Kajian Strategis Pembangunan Kesejahtraan Sosial. Bandung: Refika Aditama.

2. Sarman, M. (2004). Pengantar Metodologi Penelitian Sosial. Pustaka Fisip Unlam : Banjarmasin.
3. Nasution, S. (2003). Metode Penelitian Naturalistik Kualitatif, cet. III. Bandung: PT. Tarsito.

4. Sugiyono. (2014). Metode Penelitian Kuantitatif Kualitatif dan R\&D. Bandung : Alfabeta.

5. Bungin, B. (2008). Analisis Data Penelitian Kualitatif. Jakarta: Raja Grafindo Persada.

6. Desa, P. M., Tertinggal, P. D., \& Nomor, T. (5). tahun 2015 tentang Penetapan Prioritas Penggunaan Dana Desa Tahun 2015. Jakarta: Lembaran Negara.

7. Mulyadi, D. (2016). Studi Kebijakan Publik dan Pelayanan Publik: Konsep dan Aplikasi Proses Kebijakan Publik Berbasis Analisis Bukti Untuk Pelayanan Publik.

8. Arikunto, S. (1988). Pengelolaan Kelas dan Siswa. Jakarta: CV Rajawali.

9. Fahrudin, A. (2012). Pemberdayaan, Partisipasi dan Penguatan Kapasitas Masyarakat. Bandung: Humaniora.

10. Adi, I. R. (2008). Intervensi Komunitas dan Pengembangan. Masyarakat: Sebagai Upaya Pemberdayaan Masyarakat. Depok: PT RajaGrafindo. 